\title{
Trade-off in plant-ant interactions: seasonal variations
}

\author{
J. Martins ${ }^{a}$ (D), A. Moreira ${ }^{b}$ (D) M. Assunção ${ }^{a}$ (D), A. Oliveira ${ }^{a}$ (D) and J. Almeida ${ }^{*}$

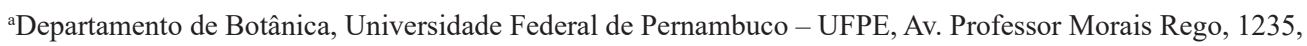 \\ Cidade Universitária, CEP 50670-901, Recife, PE, Brasil \\ bDepartamento de Ciências Biológicas, Universidade Federal de Campina Grande - UFCG, Campus Patos, \\ Av. Universitária, s/n, Santa Cecília, CEP 58708-110, Patos, PB, Brasil \\ *e-mail: jacortez@ufpe.br
}

Received: October 10, 2019 - Accepted: November 20, 2019 - Distribuited: November 30, 2020

(With 8 figures)

\begin{abstract}
This work evaluated the effect of seasonality on ant-plant interaction in a Seasonally Dry Tropical Forests, using as an ecological model the species Ipomoea carnea subs. fistulosa (Convolvulaceae). We performed systematic collection of ants, herbivores and leaves in marked plants, evaluated the efficiency of herbivorous capture by ants, and the effects of ant presence over the pollinator behavior and plant fitness in dry and rainy seasons. The presence of ants in the plants reduced the number of herbivores (dry season: $\mathrm{F}_{2.27}=4.7617, \mathrm{p}=0.0166$; rainy season: $\mathrm{F}_{2.27}=5.8655, \mathrm{p}=0.0078$ ). However, the capture efficiency was negatively affected by the presence of myrmecophilous larvae, so that the average of ants recruited on termite leaves was 2.06 ants per termite, the average recruitment of ants on larval leaves was 22.4 larva ants. In addition, the presence of ants reduced pollinator visits and promoted fruit reduction during the dry season (ANOVA: $F=3.44 ; p=0.0653$ ). In conclusion, the association with ants can result in a balance not always favorable to the host plant, and this result actually depends on abiotic (e.g. precipitation) and biotic factors (e.g. ant species composition and abundance, influence of other trophic levels and identity of associated herbivores).
\end{abstract}

Keywords: cost-benefit, biotic defense, herbivory, pollinator, seasonality.

\section{Custos e benefícios nas interações planta-formigas: variação sazonal}

\section{Resumo}

Este trabalho avaliou o efeito da sazonalidade sobre a interação planta-formiga em uma Floresta Tropical Sazonal Seca, utilizando como modelo ecológico a espécie Ipomoea carnea subs. fistulosa (Convolvulaceae). Realizamos coleta sistemática de formigas, herbívoros e folhas em plantas marcadas, avaliamos a eficiência de captura de herbívoros pelas formigas, e efeitos da presença de formigas sobre o comportamento dos polinizadores e fitness da planta nas estações seca e chuvosa. A presença de formigas nas plantas reduziu número de herbívoros (estação seca: $\mathrm{F}_{2.27}=4.7617, \mathrm{p}=0.0166$; estação chuvosa: $\left.\mathrm{F}_{2.27}=5.8655, \mathrm{p}=0.0078\right)$. No entanto, a eficiência de captura foi afetada negativamente pela presença de mirmecófilos larvas, enquanto a média de formigas recrutadas em folhas com cupins foi de 2,06 formigas por cupim, a média de recrutamento de formigas nas folhas com larvas foi de 22,4 formigas de larva. Além disso, a presença de formigas reduziu as visitas aos polinizadores e promoveu a redução de frutos durante a estação seca $(F=3.44, p=0.0653)$. Em conclusão, a associação com formigas pode resultar em um balanço nem sempre favorável à planta hospedeira, e este resultado depende de fato de fatores abióticos (e. g. precipitação) e fatores bióticos (e.g. composição e abundância de espécies de formigas, influência de outros níveis tróficos, e identidade dos herbívoros associados).

Palavras-chave: custo-benefício, defesa biótica, herbivoria, polinizador, sazonalidade.

\section{Introduction}

The interspecific interactions are considered important processes that influences patterns of morphological adaptation as both physiological and consequent variation of species (Thompson, 2013), in addition to the standards organization and community stability (Mougi and Kondoh, 2012). Such interactions are often the result of coevolution, generating spatial, temporal and number of species differences (Thompson, 2013).

When it comes to interactions between insects and plants, the ecological success of ants stands out when compared to other animal groups, being evident, among other factors, by the expressive abundance of hymenopterans in terrestrial habitats (Hölldobler and Wilson, 1990). Futhermore, interactions involving ants attract big attention because they cover a wide variety of adaptations (Rico-Gray and Oliveira, 2007), showing strong evidence to consider 
interactions between ants and plants as 'cornerstone' in many communities, especially in the tropics (Blüthgen et al., 2000; Rosumek et al., 2009).

Finding predictable and renewable food resources by ants in vegetation favors their use as a foraging substrate and explains the frequency of mutualistic relationships observed in these systems (Byk and Del-Claro, 2011). The plants resources, provided directly to the ants may be different and associated. For example, in myrmecophytes, which are nesting sites, are plants permanently inhabited by ant colonies specialize in providing plant protection (Rico-Gray and Oliveira, 2007)

Other resources are those found in myrmecophilous plants, which are not regularly occupied by ants, but frequently visited, due to: i) indirect associations with sugary exudate-producing hemiptera, known as honeydew, (Del-Claro et al., 2006) or presence of Lepidoptera larvae offering secretions (Kaminski et al., 2009); ii) the presence of extrafloral nectaries (Byk and Del-Claro, 2011). Thus, plants with EFN are very important for influencing the ant distribution.

Among the alternatives for understanding the patterns observed in ant-plant interactions, the hypothesis of "herbivorous protection" (sensu Bentley, 1977) has been intensively studied over the last three decades (Santos and Del-Claro, 2001; Vilhena-Potiguara et al., 2012; Martins et al., 2019). In Brazil, the ant-excluding has been conducted in the tropics showing that ants can indeed benefit plants reducing the impacts of herbivory (Marazzi et al., 2013).

It is noteworthy that in some cases the benefit of the association was not evidenced (O'dowd and Catchpole, 1983; Rashbrook et al., 1992), moreover the presence of myrmecophilous herbivores can completely change the role of ants in relation to plants, since these herbivores will have access to enemy-free space in the host plant because they benefit from the protection offered by the associated ants (Bächtold et al., 2016).

Moreover, beyond this classic predation view, where predators cause cascading effects when they consume their prey, other predator-transmitted effects would be non-lethal, when predator attributes elicit anti-predatory behavioral responses in their prey, affecting the entire network of trophic interactions interconnected by it (Terborgh and Estes, 2010).

This way the ants associated with extrafloral nectaries (EFN) can have bigger impact on abundance and visit rate of pollinator, causing behavioral changes in floral visitors (Martins et al., 2019), which may affect indirectly the reproductive fitness of some plant species.

However, the magnitude of costs and benefits may vary greatly due to temporal and spatial variations of some factors that influence interactions, such as abundance and richness of herbivorous insects, abundance and identity of ants, and even floral visitors (Cruz et al., 2018), which vary according to the availability and quality of plant resources. All of these factors are strongly influenced by climatic seasonality, with few studies evaluating the effects of seasonality on the cost and benefit variation of these interactions in Seasonally Dry Tropical Forests (Díaz-Castelazo et al., 2013; Rico-Gray and Oliveira, 2007).

Therefore, this paper aims to test the hypotheses: H1) Plants with greater ant diversity are less visited by herbivorous insects; H2) Greater ant diversity leads to decrease in herbivory rate; H3) The patrolling of EFNassociated ants negatively affects the reproductive fitness of the plant; H4) Myrmecophilous herbivores attract more ants to host plants. The species Ipomoea carnea subs. fistulosa (Convolvulaceae) was used as an ecological model.

\section{Material and Methods}

\subsection{Study system and study site}

Ipomoea carnea subsp. fistulosa (Martius and Choisy) belongs to the monophyletic family Convolvulaceae, widely distributed in the tropics (Junqueira and Simão-Bianchini, 2006). This species is a perennial shrub, common in Brazil due to its cultivation as an ornamental plant, native to South America (Antoniassi et al., 2007). The plant has ephemeral flowers, diurnal and reproductive system with self-incompatibility strategy (Paz et al., 2013). This species attracts several ant species due to the presence of extrafloral nectaries (EFN), two located on the abaxial leaf surface, five in the floral receptacle, and are also present and active in the floral buds (Martins et al., 2019).

The field experiment was developed at Fazenda Tamanduá, Santa Terezinha, Paraíba ( $7^{\circ} 2$ '20"south latitude and $37^{\circ} 26^{\prime} 43^{\prime \prime}$ west longitude), distant $18 \mathrm{~km}$ from the city of Patos and $320 \mathrm{~km}$ from the capital, João Pessoa (Andrade et al., 2008). The Köppen-Geiger climate classification is Bsh type. This region is inserted in the semiarid Northeast, and is marked by droughts and erratic rains irregularly distributed throughout the year. The highest precipitation rates occur between January and April, with an annual average of $600 \mathrm{~mm}$. The dry season usually starts in June and extends to January with the predominance of Caatinga formation with hot and dry climate (Cabral et al., 2013). The entire experimental design took place in a secondary succession border area, in the dry season between July and September 2018 and during the rainy season between February and May 2019, in an area in secondary succession stage (see Figure 1).

\subsection{Experiment 1: Seasonal variations of the influence of EFN-associated ant patrolling over herbivore abundance and herbivory index}

\subsubsection{Objective}

To evaluate if whether increased ants richness and abundance reduce the number of herbivores and herbivorous leaf area.

\subsubsection{Procedure}

We marked thirty individuals of Ipomoea carnea subs. fistulosa and quantified the number of branches of each plant in order to obtain a measure of the structural complexity of the plants and to test if it causes variation in abundance and richness of ants and herbivores. Subsequently we actively collected ants and herbivores using a manual 


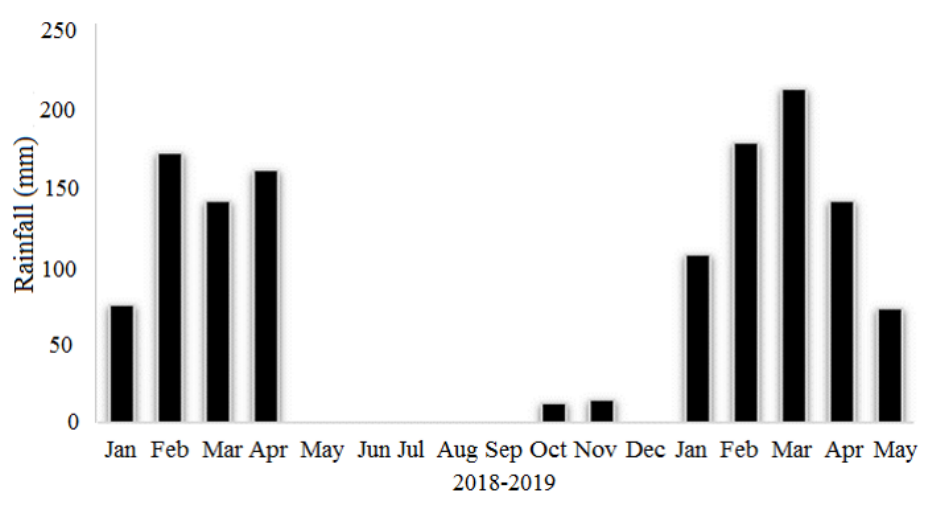

Figure 1. Rainfall in Santa Terezinha, Paraíba, Brazil.

entomological aspirator and tongs for manual collection for 20 minutes in each plant. For each of these plants, we selected a branch to avoid leaves at different stages of development, and then randomly selected 10 leaves to be removed, totaling 300 leaves that were scanned to analyze the herbivorous area using the Image J program (Rasband, 2011). We performed on each leaf the calculation consisting the summing the values of each herbivory mark over the value of the total area. Then we calculated the average proportion of the area that suffered herbivory in each plant (Adami-Rodrigues et al., 2004).

\subsection{Experiment 2: Seasonal variation of ant efficiency in herbivore capture}

Objective: To evaluate the ant efficiency in eliminating herbivores from plants patrolled by them and factors that may affect this efficiency.

Procedure: We performed tests using live termites of the Termitidae family as an ecological model of herbivores which were placed on a leaf that we randomly select, and later we measure the time of encounter, attack and removal of the termites by the ants. We performed 30 repetitions, and for each repetition we used a different plant (adapted from Vasconcelos, 1993).

Due to the occurrence of Lepidoptera mirmecophilous larvae of the Lycaenidae family during the rainy season, this experiment was repeated in 30 plants hosted by the larvae, following the same methodology previously described, with 30 replications, to evaluate the efficiency of ants in herbivore capture in detriment to the occurrence of these larvae. In addition, we evaluated the number of ants recruited for the elimination of each termite, just as we quantified the ants recruited when the leaves were exposed to the larvae. For this, we selected 60 plants without the occurrence of larvae to avoid influences. We used 30 plants for termite treatment and 30 for Lycaenidae larvae treatment, so we quantified the number of ants in exposed leaf to termites and larvae at time intervals of 2, 4, 6, 8 and 10 minutes. Subsequently, we randomly selected 30 plants hosted by the larvae and collected 10 leaves from each plant that were scanned and have the herbivorous leaf area evaluated using the Image J program (Rasband, 2011).

\subsection{Experiment 3: Variation of the effect of EFN ant patrolling over pollinator visitation rate and reproductive fitness}

Objective: To evaluate the effect of ants over flowers visitors and on plant reproductive success.

Procedure: We isolated 60 buds from 30 plants in papers bag the day before the experiment, of which we assigned 30 buds to the control group and 30 plants to the treatment group, which we manually removed all ants and applied a resin Tangle Foot ${ }^{\circledR}$ at $15 \mathrm{~cm}$ from the inflorescence. This resin is non-toxic and acts as a physical barrier preventing ant access to the plant.

The experiment had a randomized blocks design $(\mathrm{n}=30)$, each block consisting of 2 experimental units (two flowers) each received the following treatments: (1) control (flower without ants -inflorescence treated with tangle foot); (2) flower with free access to ants - untreated inflorescence with tangle foot resin. All flowers in each block were at least $30 \mathrm{~cm}$ apart to minimize any effect of ants on visitation rate of other controlled flowers. We observed the experimental flowers at a distance of at least $2 \mathrm{~m}$, avoiding an observer influence on the behavior of the visiting insects.

To quantify the number of visits and refuse (when individuals evaluate and then avoid landing) on each flower of the trio, we performed the observations simultaneously, quantifying the number of visits in each block for 10 minutes, totaling $50 \mathrm{~min}$ of each hour. These observations occurred from 6 am to $1 \mathrm{pm}$ with 10-minute intervals every hour. Subsequently, we isolated the flowers again for fruiting observation and distinguished the treatments by the use of ribbons of different colors (Martins et al., 2019).

\section{Statistical Analysis}

To test if ant richness and abundance caused herbivore reduction, we performed a multiple linear regression, and used the herbivore abundance as the dependent variable and ant abundance and richness as explanatory variables. Possible differences in richness and abundance of ant and herbivore between seasons were evaluated by the paired T-test. We evaluated if the structural complexity of the plants influenced the richness and abundance of ants and 
herbivores by performing a Simple Linear Regression for each season. In addition, we evaluated if the increasing ant richness and abundance reduced the herbivory with a Multiple Linear Regression, using the average proportion of herbivorous leaf area as a dependent variable and ant richness and abundance as an explanatory variables. We compared the encounter, attack, and removal times that ants performed to eliminate termites using Analysis of Variance (ANOVA) with one factor. We evaluated possible differences in the number of patrolled ants in plants with termite and in plants with Lycaenidae larvae using a non-parametric Kruskal-Wallis test. Finally, we tested the differences in the number of visits between treatments of ant patrolling experiments by a randomized block Analysis of Variance. Regarding the number of fruits formed in the flowers of each treatment, we compared using an Analysis of Variance (ANOVA) with one factor. However, before the analysis, we tested the variances through the Shapiro-Wilk test and when were needed, we transformed the data into square root to reduce the differences between variances. All data were analyzed at $0.05 \%$ significance through the STATISTICA 13.3 program (STATSOFT, 2017).

\section{Results}

\subsection{Influence of EFN-associated ants on leaf herbivory, herbivore richness and abundance}

We collected a total of 2.514 ant individuals, 43 morphospecies, and 4 subfamilies. Of this total, 642 occurred in the dry season with 27 morphospecies. For the rainy season, we recorded 1.872 individuals and 24 morphospecies. The ant abundance was significantly higher during the rainy season (paired T-test: $\mathrm{t}=-2.9826$, $\mathrm{p}=0.0029)$ (see Figure 2).

Among the Formicidae, the subfamily Myrmicinae was the most abundant in both seasons, followed by Formicinae, but there was no significant difference in ant richness between the dry and rainy seasons (paired T-test: $\mathrm{t}=-0.8064, \mathrm{p}=0.2133$ ) (see Figure 2). The subfamilies Myrmicinae and Formicinae showed the highest richness in both seasons, followed by Pseudomyrmecinae and Dolichoderinae. We point out that for a total of 44 recorded species, only seven morphospecies occurred during both

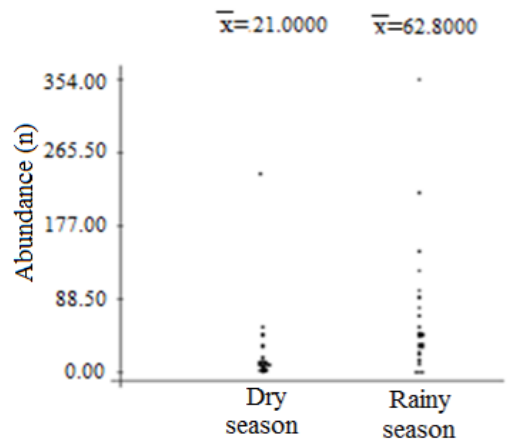

seasons (as shown in Table 1), while the other morphospecies occurred either during the dry season or during the rainy season. We collected 1.240 individuals from herbivorous insects. The most abundant order was Coleoptera with 1.210 individuals, followed by Hemiptera with 21 individuals, and Orthoptera with 9, besides collecting 35 larvae. Among the herbivores, there were 60 morphospecies, so the order with the highest richness was Coleoptera with 48 morphospecies (as shown in Table 2).

During the dry season, we recorded 907 Coleoptera individuals, distributed in 6 families and 32 morphospecies. The Hemiptera showed only seven individuals from three families and four morphospecies. During the rainy season, we recorded 303 Coleoptera individuals, distributed in five families and 24 morphospecies. The order Hemiptera had only 14 individuals, distributed in five families and seven morphospecies, besides the Orthoptera order with only one morphospecies (as shown in Table Table 2). Thus, both richness (paired T-test: $\mathrm{t}=2.6807, \mathrm{p}=0.006$ ) and abundance (paired t-test: $t=2.5128, p=0.0089$ ) were higher during the dry season.

The proportion of herbivorous leaf area per plant was also higher during this season (Paired T-test $=t=4.2461$, $\mathrm{p}<0.0001)$ coinciding with the season of lower ant abundance and higher herbivore abundance and richness (see Figure 3).

Plant structural complexity, measured by the number of branches during the dry season, influenced ant richness $(F=5.5336, p=0.0245$, see Figure 4), but did not influence abundance $(\mathrm{F}=1.4686, \mathrm{p}=0.234)$. It did not influence the richness $(\mathrm{F}=0.5030, \mathrm{p}=0.509)$ and abundance $(\mathrm{F}=1.3809, \mathrm{p}=0.2486)$ of herbivores for this season. During the rainy season the structural complexity of the plants did not influence the richness $(F=0.997, p=0.6725)$ and abundance $(\mathrm{F}=1.3812, \mathrm{p}=0.2485)$ of herbivores, nor did it influence the richness $(\mathrm{F}=0.0014, \mathrm{p}=0.969)$.) and abundance $(\mathrm{F}=1.578, \mathrm{p}=0.2172)$ of ants.

Increasing ant abundance and richness reduced herbivore abundance in the dry season $\left(\mathrm{F}_{2.27}=4.7617, \mathrm{p}=0.0166\right)$ and in the rainy season $\left(\mathrm{F}_{2.27}=5.8655, \mathrm{p}=0.0078\right)$, so that more abundant plants and ant richness presented a lower herbivore abundance (see Figure 5). Likewise, plants with

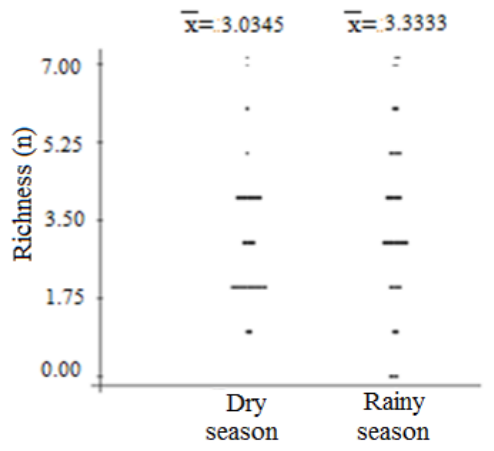

Figure 2. Abundance and richness of ants associated with Ipomoea carnea subs. fistulosa EFNs during the dry and rainy season in Caatinga ecosystem. 
Table 1. Formicidae abundance associated with Ipomoea Carnea subs. fistulosa EFNs during the dry and rainy season in Caatinga ecosystem, separated according to their subfamilies.

\begin{tabular}{|c|c|c|c|}
\hline \multicolumn{2}{|c|}{ FORMICIDAE } & \multicolumn{2}{|c|}{ ABUNDANCE } \\
\hline SUBFAMILY & Morphospecies & Dry season & Rainy season \\
\hline \multirow[t]{19}{*}{ Myrmicinae } & Myrmicinae sp1 & 9 & 0 \\
\hline & Myrmicinae sp2 & 1 & 0 \\
\hline & Myrmicinae sp3 & 1 & 0 \\
\hline & Myrmicinae sp4 & 259 & 0 \\
\hline & Myrmicinae sp5 & 1 & 0 \\
\hline & Myrmicinae sp6 & 0 & 0 \\
\hline & Myrmicinae sp7 & 1 & 0 \\
\hline & Myrmicinae sp8 & 22 & 0 \\
\hline & Myrmicinae sp9 & 30 & 0 \\
\hline & Myrmicinae sp10 & 7 & 0 \\
\hline & Myrmicinae sp11 & 0 & 11 \\
\hline & Myrmicinae sp12 & 0 & 2 \\
\hline & Myrmicinae sp13 & 0 & 178 \\
\hline & Myrmicinae sp14 & 0 & 7 \\
\hline & Myrmicinae sp15 & 0 & 55 \\
\hline & Myrmicinae sp16 & 0 & 689 \\
\hline & Myrmicinae sp17 & 0 & 1 \\
\hline & Myrmicinae sp18 & 0 & 15 \\
\hline & Myrmicinae sp19 & 0 & 14 \\
\hline \multirow[t]{15}{*}{ Formicinae } & Formicinae sp1 & 53 & 582 \\
\hline & Formicinae sp2 & 6 & 62 \\
\hline & Formicinae sp3 & 64 & 10 \\
\hline & Formicinae sp4 & 7 & 0 \\
\hline & Formicinae sp5 & 89 & 0 \\
\hline & Formicinae sp6 & 6 & 0 \\
\hline & Formicinae sp7 & 1 & 1 \\
\hline & Formicinae sp8 & 24 & 0 \\
\hline & Formicinae sp9 & 0 & 28 \\
\hline & Formicinae sp 10 & 0 & 171 \\
\hline & Formicinae sp11 & 0 & 6 \\
\hline & Formicinae sp12 & 0 & 4 \\
\hline & Formicinae sp13 & 0 & 4 \\
\hline & Formicinae sp14 & 0 & 1 \\
\hline & Formicinae sp15 & 0 & 1 \\
\hline \multirow[t]{5}{*}{ Dolichoderinae } & Dolichoderinae sp1 & 1 & 0 \\
\hline & Dolichoderinae sp2 & 4 & 0 \\
\hline & Dolichoderinae sp3 & 3 & 0 \\
\hline & Dolichoderinae sp4 & 35 & 0 \\
\hline & Dolichoderinae sp5 & 3 & 0 \\
\hline \multirow[t]{5}{*}{ Pseudomyrmecinae } & Pseudomyrmecinae sp1 & 2 & 1 \\
\hline & Pseudomyrmecinae sp2 & 8 & 23 \\
\hline & Pseudomyrmecinae sp3 & 2 & 5 \\
\hline & Pseudomyrmecinae sp4 & 3 & 0 \\
\hline & Pseudomyrmecinae sp5 & 0 & 1 \\
\hline TOTAL & & 642 & 1872 \\
\hline
\end{tabular}


Table 2. Abundance of herbivores, Separated by Orders and Families.

\begin{tabular}{|c|c|c|c|}
\hline \multicolumn{2}{|c|}{ ORDER/FAMILY } & \multicolumn{2}{|c|}{ ABUNDANCE } \\
\hline COLEOPTERA & Morphospecies & Dry season & Rainy season \\
\hline \multirow[t]{34}{*}{ Chrysomelidae } & Galerucinae sp1 & 26 & 6 \\
\hline & Galerucinae sp2 & 1 & 240 \\
\hline & Galerucinae sp3 & 11 & 0 \\
\hline & Alticinae sp1 & 2 & 6 \\
\hline & Alticinae sp2 & 1 & 0 \\
\hline & Alticinae sp3 & 4 & 0 \\
\hline & Alticinae sp4 & 18 & 0 \\
\hline & Alticinae sp5 & 4 & 0 \\
\hline & Alticinae sp6 & 2 & 0 \\
\hline & Alticinae sp7 & 2 & 0 \\
\hline & Alticinae sp8 & 0 & 1 \\
\hline & Alticinae sp9 & 0 & 7 \\
\hline & Alticinae sp10 & 1 & 0 \\
\hline & Alticinae sp11 & 2 & 0 \\
\hline & Bruchinae sp1 & 4 & 1 \\
\hline & Bruchinae sp2 & 4 & 0 \\
\hline & Bruchinae sp3 & 1 & 1 \\
\hline & Bruchinae sp4 & 10 & 0 \\
\hline & Bruchinae sp5 & 1 & 1 \\
\hline & Bruchinae sp6 & 2 & 0 \\
\hline & Bruchinae sp7 & 1 & 1 \\
\hline & Bruchinae sp8 & 1 & 0 \\
\hline & Bruchinae sp9 & 2 & 0 \\
\hline & Bruchinaesp10 & 0 & 1 \\
\hline & Bruchinae sp11 & 0 & 2 \\
\hline & Cryptocephalinae sp1 & 0 & 3 \\
\hline & Criptocephalinae sp2 & 2 & 0 \\
\hline & Cryptocephalinae sp3 & 0 & 1 \\
\hline & Cassidinae sp1 & 0 & 3 \\
\hline & Cassidinae sp2 & 0 & 1 \\
\hline & Cassidinae sp3 & 0 & 1 \\
\hline & Cassidinae sp4 & 786 & 4 \\
\hline & Eumopinae sp1 & 0 & 2 \\
\hline & Chrysomelidae sp1 & 2 & 0 \\
\hline \multirow[t]{4}{*}{ Curculionidae } & Curculionidae sp1 & 1 & 0 \\
\hline & Curculionidae sp2 & 1 & 0 \\
\hline & Curculionidae sp3 & 0 & 0 \\
\hline & Curculionidae sp4 & 1 & 0 \\
\hline \multirow[t]{2}{*}{ Erotylidae } & Erotylidae sp1 & 8 & 1 \\
\hline & Erotylidae sp2 & 2 & 0 \\
\hline \multirow[t]{2}{*}{ Buprestidae } & Buprestidae sp1 & 0 & 1 \\
\hline & Buprestidae sp2 & 0 & 3 \\
\hline \multirow[t]{2}{*}{ Lampyridae } & Lampyridae sp1 & 2 & 0 \\
\hline & Lampyridae sp2 & 0 & 1 \\
\hline Tenebrionidae & Tenebrionidae sp1 & 0 & 14 \\
\hline Cerambycidae & Cerambycidae sp 1 & 0 & 1 \\
\hline Nitidulidae & Conotelus sp 1 & 1 & 0 \\
\hline Anobiidae & Anobiidae sp1 & 1 & 0 \\
\hline
\end{tabular}


Table 2. Continued...

\begin{tabular}{llcc}
\hline \multicolumn{1}{c}{ ORDER/FAMILY } & & ABUNDANCE \\
\hline Hemiptera & Aphidoidea sp1 & 0 & 1 \\
Aphidoidea & Aphidoidea sp2 & 4 & 0 \\
Cicadeliidae & Cicadeliidae sp1 & 1 & 0 \\
& Cicadeliidae sp2 & 0 & 1 \\
& Cicadeliidae sp3 & 0 & 1 \\
Cyrrhocoridae & Cicadeliidae sp4 & 1 & 0 \\
& Pyrrhocoridae sp1 & 0 & 1 \\
Geocoridae & Pyrrhocoridae sp2 & 0 & 5 \\
Rhopalidae & Geocoridae sp1 & 0 & 4 \\
Grthoptera & Geocoridae sp2 & 1 & 0 \\
Acrididae & Rhopalidae sp1 & 0 & 1 \\
TOTAL & & & 9 \\
\hline
\end{tabular}


Figure 3. Abundance and richness of herbivorous insects and proportion of herbivorous leaf area in Ipomoea carnea subs. fistulosa during the dry and rainy season in Caatinga ecosystem.



Figure 4. Linear regression between plant structural complexity and ant richness in the dry period.

higher ant abundance and richness had lower proportion of herbivorous leaf area during the dry season $\left(\mathrm{F}_{2.27}=3.9925\right.$, $\mathrm{p}=0.0295)$, but not during the rainy season $\left(\mathrm{F}_{2.27}=0.8072\right.$, $\mathrm{p}=0.5398)$.

\subsection{Temporal variation of ant efficiency in termite capture}

Most termite encounters, attacks, and removals occurred between zero and one minute in the dry and rainy seasons (see Figure 6). There was no significant difference in the time $(\mathrm{F}=0.4656, \mathrm{p}=0.5047)$ taken by ants to find termites between year seasons (Dry season $=00 \mathrm{~min}$ : $22 \mathrm{~s}, \mathrm{n}=30$; Rainy season $=00 \mathrm{~min}: 13 \mathrm{~s}, \mathrm{n}=30$ ). However, the attack time (average dry period $=00 \mathrm{~min}$ : $56 \mathrm{~s}$; rainy $=00 \mathrm{~min}$ : $05 \mathrm{~s})(\mathrm{F}=7.8315, \mathrm{p}=0.007)$ and removal (mean dry period $=1$ minute: 48 seconds; rainy $=00 \mathrm{~min}: 15 \mathrm{~s}$ ) $(\mathrm{F}=17.7361, \mathrm{p}=0.0002)$ was lower during the rainy season.

The occurrence of Lepidoptera larvae of the Lycaenidae family on leaves of I. carnea subs. fistulosa during the rainy season negatively affected the efficiency of termite capture by ants.

Thus, of the 30 termites that were placed on leaves of larvae plants, only 3 of them were eliminated from the plants and all by a single ant. Ants recruitment was also different in termites and larvae plants, while the average of ants recruited on termite leaves was 2.06 ants per termite, the average recruitment of ants in larvae leaves 

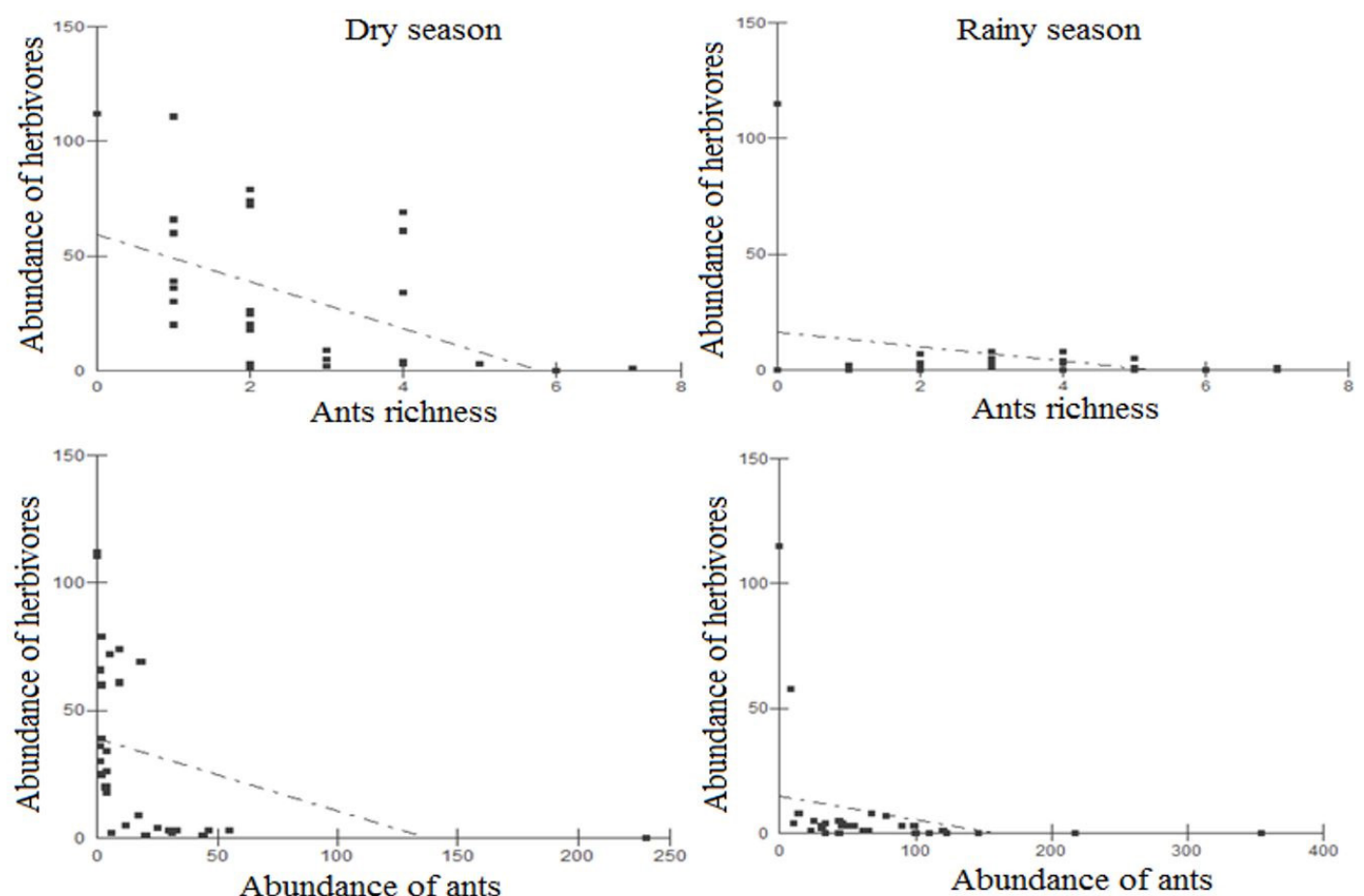

Figure 5. Effect of ant abundance and richness on herbivore abundance during the dry season and rainy season in Ipomoea carnea subs. fistulosa in Caatinga ecosystem.
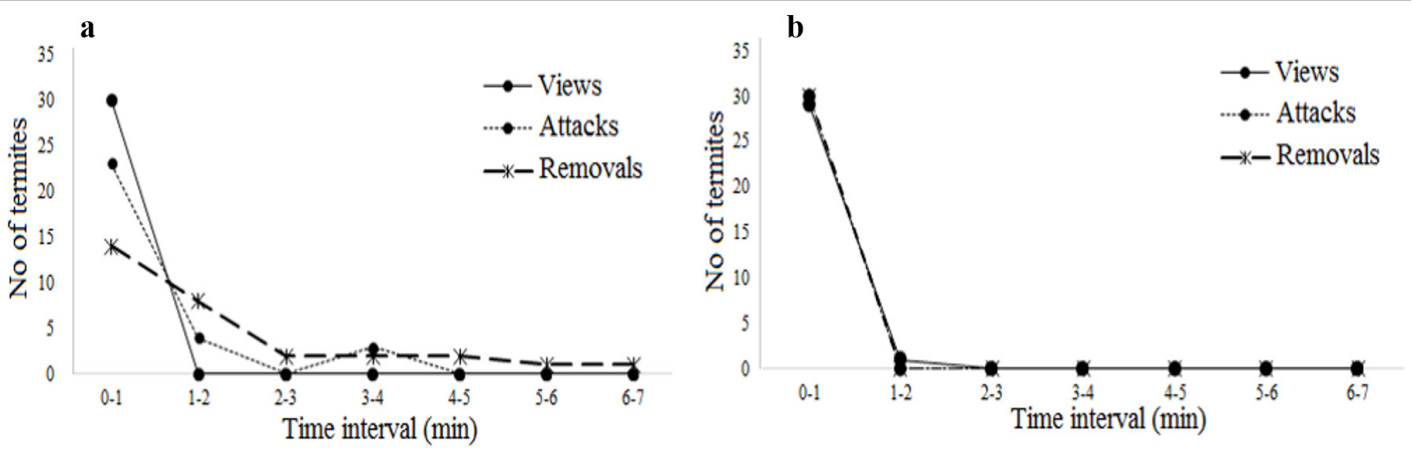

Figure 6. Number of termites found, attacked and removed by ants associated with EFNs at different time intervals in the Caatinga ecosystem. (a) Dry season; (b) Rainy season.

was 22.4 larva ants (non-parametric Kruskal-Wallis test: $\mathrm{H}=89.78, \mathrm{p}=<0.0001$ ), showing variations at different time intervals (see Figure 7).

Furthermore, the average proportion of plant herbivorous leaf area with larval occurrence was $12.31(\mathrm{n}=30$ plants, 300 leaves), while in plants without larvae it was 0.01 ( $\mathrm{n}=30$ plants, 300 leaves).

\subsection{Variation of the effect of ant patrolling of EFNs on pollinator visitation rate and reproductive fitness}

During the dry season, the flowers of I. carnea subs. fistulosa were visited by bees, wasps and flies during the experiment, totaling 957, 22 and 12 visits, respectively.
We recorded a total of 76 visits in ant-patrolled flowers, while in ant free access flowers we recorded 915 visits, with a significant difference (block randomized ANOVA: $\left.\mathrm{F}_{1.120}=43.88, \mathrm{p}<0.001\right)$ in the number of visits to flower with and without ants, so visitors were negatively affected by ant patrolling. During the rainy season, there were a total of 446 bee visits, 46 fly visits and 9 wasp visits. Of this total, flowers patrolled by ants had a record of 152 visits, while isolated flowers of ants, there were a total of 349 (ANOVA randomized blocks $\mathrm{F}_{1.120}=11.61, \mathrm{p}=0.0013$ ) (see Figure 8).

The number of avoidances during the dry season for bees, wasps and flies was 125,95 and 6 respectively. We recorded 
a total of 226 avoidances, of which 97 in branch flowers with ants and 129 avoidances in branch flowers without ants (randomized block ANOVA: $\mathrm{F}_{1.120}=1.24, \mathrm{p}=0.0297$ ).

It is noteworthy that all the droppings recorded in flowers without ants, was due to the previous presence of bees within the flowers at the time of some visits, so the bees avoided flowers that were already occupied by other bees. This occurred differently in flowers without ants, where visitors clearly avoided the flowers by the presence of ants that exhibited aggressive behavior, promptly advancing toward the pollinators, who in turn gave up completing the visit (see Figure 8).

During the rainy season, there was a greater number of avoidances in ant-patrolled flowers, with significant difference (randomized block ANOVA: $\left.\mathrm{F}_{1.180}=55.75, \mathrm{p}=0.0001\right)$, occurring 148 bee avoidances, 29 wasp and 7 avoidances of flies on these flowers, totaling 184 avoidances. Regarding the flowers that were isolated from the presence of ants, there was a lower occurrence of this behavior, with 22, 28 and 22 avoidances for bees, wasps and flies, respectively totaling 72 avoidances (see Figure 8).

The significant reduction in the number of visits to ant-patrolled flowers during the dry season was negatively reflected in reproductive fitness, so ant-patrolled flowers had reproductive success of only $26.66 \%$, while flowers isolated from presence of ants had a reproductive success of $76.66 \%$ of fruiting, differing significantly (ANOVA: $\mathrm{F}=14.781, \mathrm{p}=0.0015 ;$ TUKEY: $\mathrm{p}<0.01$ )

During the rainy season, there was also a lower fruiting rate in flowers patrolled by ants, with fruiting in $46.66 \%$ of the flowers, while flowers isolated from the presence of ants showed a reproductive success of $70 \%$ of

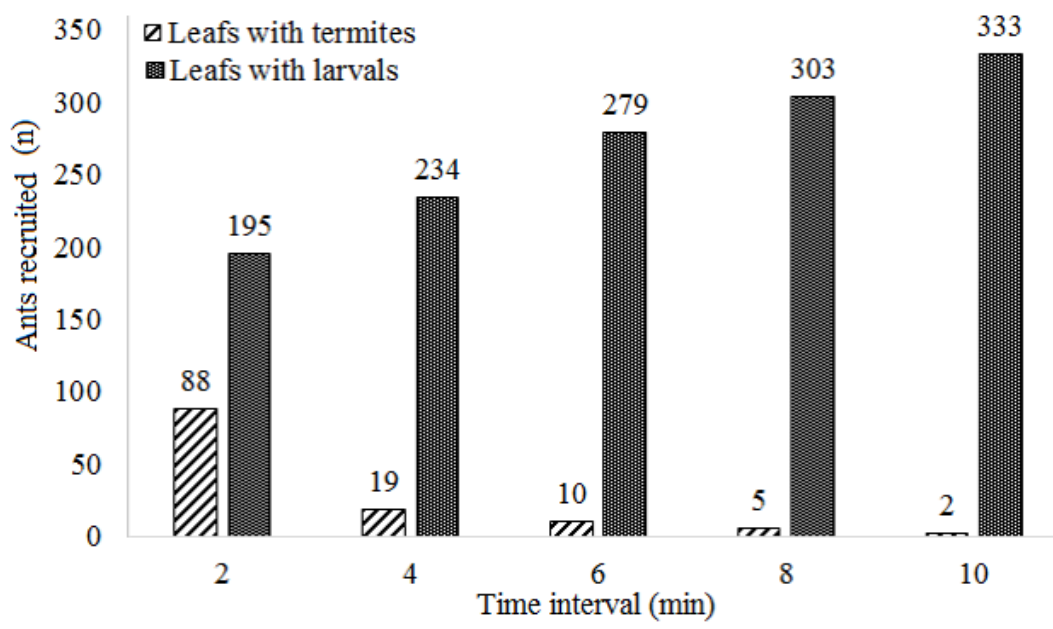

Figure 7. Mean and standard deviation of time spent by EFN-associated ants to find, to attack and to remove termites on leaves of Ipomoea carnea subs. fistulosa during the dry and rainy seasons in the Caatinga ecosystem.
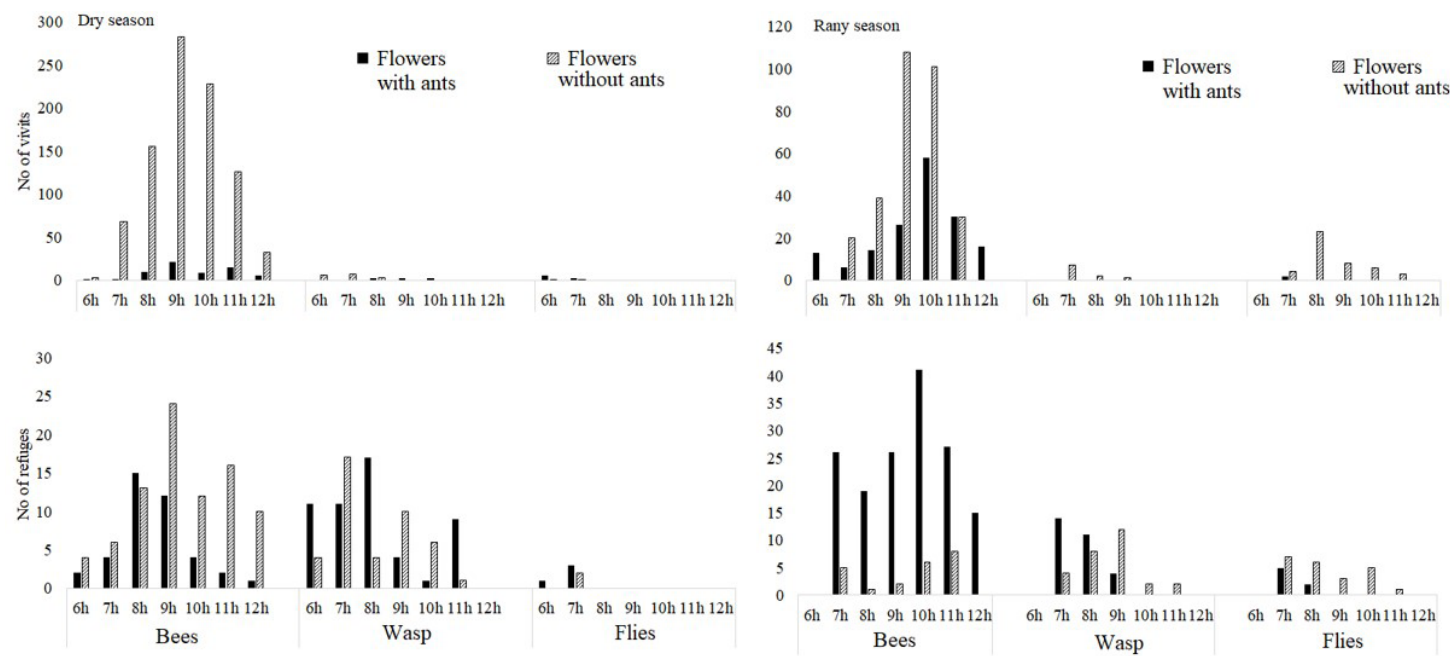

Figure 8. Number of visits and avoidances by bees, wasps and flies on flowers of Ipomoea carnea subs. fistulosa, during the dry and rainy season in Caatinga ecosystem. 
fruiting. The difference was not significant for this season (ANOVA: $\mathrm{F}=3.44, \mathrm{p}=0.0653$ ).

\section{Discussion}

\subsection{Seasonal variations of ant-plant interactions and their effects on herbivores}

Many studies claim that the highest percentages of herbivory occur in the rainy season (Aide, 1992; Coley and Barone, 1996; Gobbo-Neto and Lopes, 2007, due to the increased abundance of herbivorous insects during this period. However, for the present work the highest proportions of herbivory occurred during the dry season. Several authors (Edwards and Wratten, 1981; Bezemer and Jones, 1998; Agrell et al., 2006) have shown that factors such as nutritional conditions and climate change can bring about sudden changes in plant quality, greatly affecting insects, so plants under water or nutritional stress are considered more susceptible to herbivore attack. Making ant protection even more effective during the dry season.

During the rainy season the increase in ant abundance and richness was not related to the herbivory reduction, however, the plants presented lower herbivory index and lower herbivore abundance and richness, lower herbivory occurrence and lower Herbivore abundance and richness may be more related to the chemical defenses of the plant. In addition, some studies have shown that these associations between plants and ants are fragile and susceptible to species "cheaters" which divert the benefits of interactions only to one side (Izzo and Vasconcelos, 2002; Izzo and Peneti-Benelli, 2011).

In the present work, during the rainy season the plants were being hosted by Lepidoptera larvae of the Lycaenidae family that recruited a large number of ants that foraged the plants. There are basically two consequences for herbivorous insects in ant-plant systems (1) the high frequency of ants on the foliage has a negative effect on herbivores and limits the existence of safe, free spaces from natural enemies (Floren et al., 2002); (2) myrmecophilous herbivorous species have access to enemy-free space in the host plant because they benefit from the protection afforded by the associated ants (Pierce et al., 2002). Thus, this work brings results that show the presence of an opportunistic relationship during the rainy season, since the ants benefited not only from the extrafloral nectar, but also from the secretions produced by the larvae, while plants were no longer protected from other herbivores, while they were being consumed by larvae that caused high proportions of herbivorous area.

Myrmecophilous larvae have the ability to mimic chemical signals, morphological, and / or behavioral used in ants' intraspecific communication (Hölldobler and Wilson, 1990), being well documented for the Lycaenidae family and the nature of these interactions is considered mutualistic, since ants receive nutritious secretions produced by specialized glands (Newcomer, 1912; DeVries and Baker, 1989), and in return the larvae receive protection against predators and parasitoids (Pierce and Mead, 1981).
According to Pierce et al. (2002), myrmecophilous larvae can manipulate ant behavior in three ways: appeasing aggressive behavior, maintaining interest in symbiosis, and inducing defensive behavior. These ant behavioral responses are mediated by the myrmecophilic organs in three ways: (1) through nutritional rewards produced by glands (also called nectariferous organs); (2) by chemical communication; (3) by sound communication.

In addition, studies on the nutritional content of these secretions have shown a higher amino acid richness than that found in other available liquid food sources for ants in vegetation (DeVries and Baker, 1989), which justifies the large number of ants patrolled on plants hosted by larvae, allowing us to state that during the rainy season the efficiency of herbivore capture and plant fidelity by the ants was affected.

\subsection{Seasonal variations of the effect of ant presence on pollinator visit and plant reproductive fitness}

Mutualistic interactions are often studied focusing on pairs of species. However, species are naturally involved in multiple direct and indirect interactions, with varying results in space and time (Rudgers and Strauss, 2004; Kersch and Fonseca, 2005; Diaz-Castelazo et al., 2013). Nectar secretion can mediate mutualistic interactions by providing reward to pollinators and anti-herbivore advocates (Grasso et al., 2015). However, climate seasonality, ant abundance and identity may cause variations of these results, showing that these are in fact conditional mutualisms, which demand a cost for the plant. Other works show the existence of "trade-offs" for plants patrolled by ants (Redman et al., 2001; Cruz et al., 2019).

In the present study, ants caused a significant reduction in the number of pollinator visits, as observed by Cruz et al. (2019) and by Martins et al. (2019). According to D'Áttilo et al. (2009) only visual clues, that is, mimetic models that indicate the presence of ants are sufficient to produce such a reduction in visitors, especially bees.

The results showed a predominance of visits and avoidances by bees, and this is justified by the fact that the plant is an oligophilic melitophilous species, with promiscuous pollination, since more than one bee participates in the pollination process and have easy access to floral resources. (Faegri and Van Der Pijl, 2013). Thus, this higher behavioral response of bees to a potential predator is due to the strong pressure exerted by the predation itself(Ings and Chittka, 2009), and the bees have great vision, the high ability to detect morphological characters (Gonçalves-Souza et al., 2008), aggressive behavioral characters (Ings and Chittka, 2009), and chemical odors (Dicke and Grostal, 2001) that can be emitted by the visiting ants of EFNs.

Ipomoea carnea subs. fistulosa is a self-incompatible species, and therefore relies on pollinators for reproduction more than other plant species (Schlindwein and Medeiros 2006). Thus, the lower number of flower visits with free ant access to EFNs led to a significant reduction in fruit production during the dry season. This can be justified by considering abiotic and biotic factors. 
The scarcity of water leads the plant, even if perennial and with continuous fruiting, the lowest fruit production. This is because seasonality exposes plants to periodic changes, mainly through factors such as water, light and temperature, with plants having to physiologically adjust to these conditions (Williams and Allan, 2002) prioritizing the essential for survival in the face of water scarcity.

As for biotic factors, such as the presence of ants affecting plant-pollinator interaction, according to Bächtold et al. (2016) these interactions depend on a myriad of factors such as the identity and abundance of floral visitors, as well as the foraging and recruitment strategy of ants. Additionally, direct and indirect plant defenses require resources that limit energy investment in growth and reproduction (Redman et al., 2001). Here we see that the end result of the trade-off between breeding and protection, at least during the dry season for the host plant, so that in the presence of ants, the plants showed a significant reduction in herbivore numbers and a lower proportion of herbivores and herbivorous leaf area in both seasons (dry and rainy).

During the dry season the significant reduction in fruit production in ant-patrolled plants leads us to believe that the protection of photosynthetic tissue is more important to the plant than fruiting, other studies show this balance of cost and benefits in interactions between plants and ants (Cuautle and Rico-Gray, 2003; Nascimento and Del-Claro, 2010; Cruz et al., 2019).

Fruit reduction may also be at the expense of increased nectar production. Studies have shown that plants with EFN can increase nectar production when ants are present to optimize defensive behavior (D'Attilo et al., 2015; Grasso et al., 2015; Heil, 2015; Del-Claro et al., 2016). This would also justify the extremely aggressive behavior observed in ants visiting EFNs during the dry season, because although the species of ants associated with I. carnea vary temporally and in defensive capacity, they patrol plants (Cruz et al., 2019). Furthermore, due to their intensive patrolling, ants are likely to induce higher nectar production compared to other associated organisms, such as potential and enemy pollinators, who use nectar as their primary or alternative resource (Torres-Hernandez et al., 2000; Rafael et al., 2012), thus affecting visitation and fruiting.

Finally, we can say that we partially corroborate hypotheses $\mathrm{H} 1$ and $\mathrm{H} 4$, while hypotheses $\mathrm{H} 2$ and $\mathrm{H} 3$ we corroborated only for the dry season. In conclusion, this study showed that association with ants may result in a balance not always favorable to the host plant, but that the result actually depends on abiotic factors (e.g. precipitation) and biotic factors (e.g. composition and abundance of ant species, influence of other trophic levels, and identity of associated herbivores). Future studies may investigate the modulation of the plant in the production of extrafloral nectar related to phenological stages that in Dry Seasonal Tropical Forests has strong influence of climatic seasonality. Our results help to understand the mechanisms involved in trophic interactions within the complex network of interactions involving ants and plants and how these results are not fixed and therefore highly conditional.

\section{Acknowledgements}

To the Postgraduate Program in Plant Biology of UFPE, Tamanduá Institute for their financial and logistical support and the Brazilian Conselho Nacional de Desenvolvimento Científico e Tecnológico (CNPq - PQ 307422/2012-7 and PQ 309965/2016-0). Finally, we gratefully thank the Coordenação de Aperfeiçoamento de Pessoal de Nível Superior (CAPES), Brasil (Finace Code 001) for the financial aid.

\section{References}

ADAMI-RODRIGUES, K., IANNUZZI, R. and PINTO, I.D., 2004. Permian plant-insect interactions from a Gondwana flora of southern Brazil. Fossils and Strata, vol. 51, no. 51, pp. 106-125.

AGRELL, J., ANDERSON, P., OLESZEK, W., STOCHMAL, A. and AGRELL, C., 2006. Elevated CO2 levels and herbivore damage alter host plant preferences. Oikos, vol. 112, no. 1, pp. 63-72. http://dx.doi.org/10.1111/j.0030-1299.2006.13614.x.

AIDE, T.M., 1992. Dry season leaf production: an escape from herbivory. Biotropica, vol. 24, no. 4, pp. 532-537. http://dx.doi. org/10.2307/2389016.

ANDRADE, R.L., SOUTO, J.S., SOUTO, P.C. and BEZERRA, D.M., 2008. Deposição de serrapilheira em área de caatinga na RPPN" fazenda tamanduá", Santa Terezinha-PB. Revista Caatinga, vol. 21, no. 2, pp. 223-230.

ANTONIASSI, N.A., FERREIRA, E.V., SANTOS, C.E., ARRUDA, L.P., CAMPOS, J.L.E., NAKAZATO, L. and COLODEL, E.M., 2007. Intoxicação espontânea por Ipomoea carnea subsp. fistulosa (Convolvulaceae) em bovinos no Pantanal Matogrossense. Pesquisa Veterinária Brasileira, vol. 27, no. 10, pp. 415-418. http://dx.doi.org/10.1590/S0100-736X2007001000005.

BÄCHTOLD, A., SILVA, E.A. and DEL-CLARO, K., 2016. Ants, plant characteristics and habitat conservation status affect the occurrence of myrmecophilous butterflies on an extrafloral nectaried Malpighiaceae. Studies on Neotropical Fauna and Environment, vol. 51, no. 2, pp. 112-120. http://dx.doi.org/10.1 080/01650521.2016.1198192.

BENTLEY, B.L., 1977. Extrafloral nectaries and protection by pugnacious bodyguards. Annual Review of Ecology and Systematics, vol. 8, no. 1, pp. 407-427. http://dx.doi.org/10.1146/ annurev.es.08.110177.002203.

BEZEMER, R.M. and JONES, T.H., 1998. Plant-insect interactions in elevated atmospheric $\mathrm{CO} 2$ : quantitative analyses and guild effects. Oikos, vol. 82, no. 2, pp. 212-222. http://dx.doi. org/10.2307/3546961.

BLÜTHGEN, N., VERHAAGH, M., GOITÍA, W., JAFFÉ, K., MORAWETZ, W. and BARTHLOTT, W., 2000. How plants shape the ant community in the Amazonian rainforest canopy: the key role of extrafloral nectaries and homopteran honeydew. Oecologia, vol. 125, no. 2, pp. 229-240. http://dx.doi.org/10.1007/ s004420000449. PMid:24595834.

BYK, J. and DEL-CLARO, K., 2011. Ant-plant interaction in the Neotropical savanna: direct beneficial effects of extrafloral 
nectar on ant colony fitness. Population Ecology, vol. 53, no. 2, pp. 327-332. http://dx.doi.org/10.1007/s10144-010-0240-7.

CABRAL, G.A.L., SAMPAIO, E.V.S.B. and ALMEIDACORTEZ, J.S., 2013. Estrutura espacial e biomassa da parte aérea em diferentes estádios sucessionais de Caatinga, em Santa Terezinha, Paraíba. Revista Brasileira de Geografia Física, vol. 6, pp. 566-574. http://dx.doi.org/10.5935/1984-2295.20130057.

COLEY, P.D. and BARONE, J.A., 1996. Herbivory and plant defenses in tropical forests. Annual Review of Ecology and Systematics, vol. 27, no. 1, pp. 305-335. http://dx.doi.org/10.1146/ annurev.ecolsys.27.1.305.

CRUZ, N., CRISTALDO, P.F., BACCI, L., ALMEIDA, C.S., CAMACHO, G.P., SANTANA, A.S., RIBEIRO, E.J.M., OLIVEIRA, A.P., SANTOS, A.A. and ARAÚJO, A.P.A., 2018. Variation in the composition of ants on defense of host plant Turnera subulata (Turneraceae): strong response to simulated herbivore attacks and to herbivore's baits. Arthropod-Plant Interactions, vol. 12, no. 1, pp. 113-121. http://dx.doi.org/10.1007/ s11829-017-9559-8.

CRUZ, N.G., ALMEIDA, C.S., BACCI, L., CRISTALDO, P.F., SANTANA, A.S., OLIVEIRA, A.P., RIBEIRO, E.J.M. and ARAÚJO, A.P.A., 2019. Ant associations in the Neotropical shrub Turnera subulata (Turneraceae): costs or benefits to the host plant? Austral Ecology, vol. 44, no. 1, pp. 60-69. http://dx.doi. org/10.1111/aec.12652.

CUAUTLE, M. and RICO-GRAY, V., 2003. The effect of wasps and ants on the reproductive success of the extrafloral nectaried plant Turnera ulmifolia (Turneraceae). Functional Ecology, vol. 17, no. 3, pp. 417-423. http://dx.doi.org/10.1046/j.13652435.2003.00732.x

D'ATTILO, W., AGUIRRE, A., FLORES-FLORES, R.V., FAGUNDES, R., LANGE, D., GARCÍA-CHÁVEZ, J., DEL-CLARO, K. and RICO-GRAY, V., 2015. Secretory activity of extrafloral nectaries shaping multitrophic ant-plantherbivore interactions in an arid environment. Journal of Arid Environments, vol. 114, pp. 104-109. http://dx.doi.org/10.1016/j. jaridenv.2014.12.001

D'ÁTTILO, W., MARQUES, C.E., FALCÃO, F.J.C. and MOREIRA, D.D.O., 2009. Interações mutualísticas entre formigas e plantas. EntomoBrasilis, vol. 2, no. 2, pp. 32-36. http://dx.doi. org/10.12741/ebrasilis.v2i2.44.

DEL-CLARO, K., ARRUDA, R. and CARVALHO, L.N., 2006. Host specificity of a Brazilian mistletoe, Struthanthus aff. polyanthus (Loranthaceae), in cerrado tropical savanna. FloraMorphology, Distribution. Functional Ecology of Plants, vol. 201, no. 2, pp. 127-134. http://dx.doi.org/10.1016/j.flora.2005.07.001.

DEL-CLARO, K., RICO-GRAY, V., TOREZAN-SILINGARDI, H.M., ALVES-SILVA, E., FAGUNDES, R., LANGE, D., DÁTTILO, W., VILELA, A.A., AGUIRRE, A. and RODRIGUEZMORALES, D., 2016. Loss and gains in ant-plant interactions mediated by extrafloral nectar: fidelity, cheats, and lies. Insectes Sociaux, vol. 63, no. 2, pp. 207-221. http://dx.doi.org/10.1007/ s00040-016-0466-2.

DEVRIES, P.J. and BAKER, I., 1989. Butterfly exploitation of an ant-plant mutualism: adding insult to herbivory. Journal of the New York Entomological Society, vol. 97, no. 3, pp. 332-340.

DIAZ-CASTELAZO, C., SANCHEZ-GALVAN, I.R., GUIMARÃES JUNIOR, P.R., RAIMUNDO, R.L. and RICO-GRAY, V., 2013. Long-term temporal variation in the organization of an ant-plant network. Annals of Botany, vol. 111, no. 6, pp. 1285-1293. http:// dx.doi.org/10.1093/aob/mct071. PMid:23704116.

DICKE, M. and GROSTAL, P., 2001. Chemical detection of natural enemies by arthropods: an ecological perspective. Annual Review of Ecology and Systematics, vol. 32, no. 1, pp. 1-23. http:/ dx.doi.org/10.1146/annurev.ecolsys.32.081501.113951.

EDWARDS, P.J. and WRATTEN, S.D., 1981. Ecologia das interações entre insetos e plantas. São Paulo: EPU/Editora da Universidade de Sao Paulo, Vol. 27.

FAEGRI, K. and VAN DER PIJL, L., 2013. Principles of pollination ecology. USA: Elsevier.

FLOREN, A., BIUN, A. and LINSENMAIR, E.K., 2002. Arboreal ants as key predators in tropical lowland rainforest trees. Oecologia, vol. 131, no. 1, pp. 137-144. http://dx.doi.org/10.1007/ s00442-002-0874-z. PMid:28547503.

GOBBO-NETO, L. and LOPES, N.P., 2007. Plantas medicinais: fatores de influência no conteúdo de metabólitos secundários. Quimica Nova, vol.30, no. 2, pp. 374-381. http://dx.doi.org/10.1590/ S0100-40422007000200026.

GONÇALVES-SOUZA, T., OMENA, P.M., SOUZA, J.C. and ROMERO, G.Q., 2008. Trait-mediated effects on flowers: artificial spiders deceive pollinators and decrease plant fitness. Ecology, vol. 89, no. 9, pp. 2407-2413. http://dx.doi.org/10.1890/07-1881.1. PMid:18831161

GRASSO, D.A., PANDOLFI, C., BAZIHIZINA, N., NOCENTINI, D., NEPI, M. and MANCUSO, S., 2015. Extrafloral-nectar-based partner manipulation in plant-ant relationships. AoB Plants, vol. 7, pp. plv002. http://dx.doi.org/10.1093/aobpla/plv002. PMid:25589521

HEIL, M., 2015. Extrafloral nectar at the plant-insect interface: a spotlight on chemical ecology, phenotypic plasticity, and food webs. Annual Review of Entomology, vol. 60, no. 1, pp. 213232. http://dx.doi.org/10.1146/annurev-ento-010814-020753. PMid:25564741

HÖLLDOBLER, B. and WILSON, E.O., 1990. The ants. Harvard: Harvard University Press. http://dx.doi.org/10.1007/9783-662-10306-7.

INGS, T.C. and CHITTKA, L., 2009. Predator crypsis enhances behaviourally mediated indirect effects on plants by altering bumblebee foraging preferences. Proceedings of the Royal Society B: Biological Sciences, vol. 276, no. 1664, pp. 2031-2036. http:// dx.doi.org/10.1098/rspb.2008.1748.

IZZO, T.J. and PENETI-BENELLI, A., 2011. Relação entre diferentes espécies de formigas e a mirmecófita Cordia nodosa Lamarck (Boraginaceae) em áreas de mata ripária na Amazônia mato-grossense. Acta Amazonica, vol. 41, no. 3, pp. 355-360. http://dx.doi.org/10.1590/S0044-59672011000300004.

IZZO, T.J. and VASCONCELOS, H.L., 2002. Cheating the cheater: domatia loss minimizes the effects of ant castration in an Amazonian ant-plant. Oecologia, vol. 133, no. 2, pp. 200-205. http://dx.doi.org/10.1007/s00442-002-1027-0. PMid:28547307.

JUNQUEIRA, M.E.R. and SIMÃO-BIANCHINI, R., 2006. O gênero Evolvulus L. (Convolvulaceae) no município de Morro do Chapéu, BA, Brasil. Acta Botanica Brasilica, vol. 20, no. 1, pp. 152-172. http://dx.doi.org/10.1590/S0102-33062006000100015.

KAMINSKI, L.A., SENDOYA, S.F., FREITAS, A.V.L. and OLIVEIRA, P.S., 2009. Ecologia comportamental na interface 
formiga-planta-herbívoro: interações Entre formigas e lepidópteros. Oecologia Brasiliensis, vol. 13, pp. 27-44.

KERSCH, M.F. and FONSECA, C.R., 2005. Abiotic factors and the conditional outcome of an ant-plant mutualism. Ecology, vol. 86, no. 8, pp. 2117-2126. http://dx.doi.org/10.1890/04-1916.

MARAZZI, B., BRONSTEIN, J.L. and KOPTUR, S., 2013. The diversity, ecology and evolution of extrafloral nectaries: current perspectives and future challenges. Annals of Botany, vol. 111, no. 6, pp. 1243-1250. http://dx.doi.org/10.1093/aob/ mct109. PMid:23704115.

MARTINS, J., CARNEIRO, A., SOUZA, L. and ALMEIDACORTEZ, J., 2019. How pollinator visits are affected by flower damage and ants presence in Ipomoea carnea subs. fistulosa (Martius and Choise) (Convolvulaceae)?. Brazilian Journal of Biology = Revista Brasileira de Biologia, In press. http://dx.doi. org/10.1590/1519-6984.189025.

MOUGI, A. and KONDOH, M., 2012. Diversity of interaction types and ecological community stability. Science, vol. 337, no. 6092, pp. 349-351. http://dx.doi.org/10.1126/science.1220529. PMid:22822151.

NASCIMENTO, E.A. and DEL-CLARO, K., 2010. Ant visitation to extrafloral nectaries decreases herbivory and increases fruit set in Chamaecrista debilis (Fabaceae) in a Neotropical savanna. Flora - Morphology Distribution Functional Ecology of Plants, vol. 205, no. 11, pp. 754-756. https://doi.org/10.1016/j.flora.2009.12.040.

NEWCOMER, E.J., 1912. Some observations on the relations of ants and lycaenid caterpillars, and a description of the relational organs of the latter. Journal of the New York Entomological Society, vol. 20, no. 1, pp. 31-36.

O'DOWD, D.J. and CATCHPOLE, E.A., 1983. Ants and extrafloral nectaries: no evidence for plant protection in Helichrysum spp.ant interactions. Oecologia, vol. 59, no. 2-3, pp. 191-200. http:// dx.doi.org/10.1007/BF00378837. PMid:28310233.

PAZ, J.R.L., GIMENES, M. and PIGOZZO, C.M., 2013. Floral biology of the morning glory Ipomoea carnea subsp. fistulosa (Mart. ex Choisy) DF Austin (Convolvulaceae) in an anthropic area of the semiarid region of Brazil, with emphasis on diurnal and nocturnal pollination. Flora, vol. 208, pp. 138-146.

PIERCE, N.E. and MEAD, P.S., 1981. Parasitoids as selective agents in the symbiosis between lycaenid butterfly larvae and ants. Science, vol. 211, no. 4487, pp. 1185-1187. http://dx.doi. org/10.1126/science.211.4487.1185. PMid:17755156.

PIERCE, N.E., BRABY, M.F., HEATH, A., LOHMAN, D.J., MATHEW, J., RAND, D.B. and TRAVASSOS, M.A., 2002. The ecology and evolution of ant association in the Lycaenidae (Lepidoptera). Annual Review of Entomology, vol. 47, no. 1, pp. 733-771. http://dx.doi.org/10.1146/annurev.ento.47.091201.145257. PMid:11729090.

RAFAEL, J.A., MELO, G.A.R. and CARVALHO, C.J.B., 2012 eds. Insetos do Brasil: diversidade e taxonomia. Ribeirão Preto: Holos Editora.

RASBAND, W., 2011. ImageJ documentation. USA: RSB.

RASHBROOK, V.K., COMPTON, S.G. and LAWTON, J.H., 1992. Ant-herbivore interactions: reasons for the absence of benefits to a fern with foliar nectaries. Ecology, vol. 73, no. 6, pp. 2167-2174. http://dx.doi.org/10.2307/1941464.
REDMAN, A.M., CIPOLLINI JUNIOR, D.F. and SCHULTZ, J.C., 2001. Fitness costs of jasmonic acid-induced defense in tomato, Lycopersicon esculentum. Oecologia, vol. 126, no. 3, pp. 380385. http://dx.doi.org/10.1007/s004420000522. PMid:28547452.

RICO-GRAY, V. and OLIVEIRA, P.S., 2007. The ecology and evolution of ant-plant interactions. Chicago: University of Chicago Press. http://dx.doi.org/10.7208/chicago/9780226713540.001.0001.

ROSUMEK, F.B., SILVEIRA, F.A.O., NEVES, F.S., BARBOSA, N.P.U., DINIZ, L., OKI, Y., PEZZINI, F., FERNANDES, G.W. and CORNELISSEN, T., 2009. Ants on plants: a meta-analysis of the role of ants as plant biotic defenses. Oecologia, vol. 160, no. 3, pp. 537-549. http://dx.doi.org/10.1007/s00442-009-1309-x. PMid:19271242.

RUDGERS, J.A. and STRAUSS, S.Y., 2004. A selection mosaic in the facultative mutualism between ants and wild cotton. Proceedings of the Royal Society, vol. 271, no. 1556, pp. 24812488. http://dx.doi.org/10.1098/rspb.2004.2900. PMid:15590599.

SANTOS, J.C. and DEL-CLARO, K., 2001. Interação entre formigas, herbívoros e nectários extraflorais em Tocoyena formosa (Cham. \& Schlechtd.) K. Schum.(Rubiaceae) na vegetação do cerrado. Revista Brasileira de Zoociências, vol. 3, no. 1, pp. 2021 p.

SCHLINDWEIN, C. and MEDEIROS, P.C., 2006. Pollination in Turnera subulata (Turneraceae): unilateral reproductive dependence of the narrowly oligolectic bee Protomeliturga turnerae (Hymenoptera, Andrenidae). Flora-Morphology, Distribution, Functional Ecology of Plants, vol. 201, no. 3, pp. 178-188. http:// dx.doi.org/10.1016/j.flora.2005.07.002.

STATSOFT, 2017. Programa computacional Statistica. Versão 7.0. 2004. Tulsa: Statsoft Inc.

TERBORGH, J., and ESTES, J. A., editors, 2010. Trophic cascades: predators: prey, and the changing. DC: Island Press.

THOMPSON, J.N., 2013. Relentless evolution. Oxford: University of Chicago Press. 512 p. http://dx.doi.org/10.7208/ chicago/9780226018898.001.0001.

TORRES-HERNANDEZ, L., RICO-GRAY, V., CASTILLOGUEVARA, C. and VERGARA, J.A., 2000. Effect of nectarforaging ants and wasps on the reproductive fitness of Turnera ulmifolia (Turneraceae) in a coastal sand dune in Mexico. Acta Zoológica Mexicana, vol. 81, pp. 13-21.

VASCONCELOS, H.L., 1993. Ant colonization of Maieta guianensis seedlings, an Amazon ant-plant. Oecologia, vol. 95, no. 3, pp. 439-443. http://dx.doi.org/10.1007/BF00321000. PMid:28314022.

VILHENA-POTIGUARA, R.C., AGUIAR-DiAS, A.C.A., KIKUCHI, T.Y.S., SANTOS, A.C.F. and SILVA, R.J.F., 2012. Secretory structures in cipó-d'alho (Mansoa standleyi (Steyerm.) AH Gentry, Bignoniaceae): occurrence and morphology. Acta Amazonica, vol. 42, no. 3, pp. 321-328. http://dx.doi.org/10.1590/ S0044-59672012000300003.

WILLIAMS, R.J. and ALLAN, G.A.G., 2002. Fire regimes and biodiversity in the wet-dry tropical savanna landscapes of northern Australia. In: R.A. BRADSTOCK, J.E. WILLIAMS and M.A. GILL, eds. Flammable Australia: the fire regimes and biodiversity of continent. Cambridge: Cambridge University Press, pp. 281-304. 